\title{
From Economic to Political Crisis? Dynamics of Contention in Russian Regions (2008-2012)
}

\author{
Andrey Semenov ${ }^{1, *}$ \\ 1 Center for Comparative History and Politics, Perm State University, Russia \\ * E-Mail: andreysemenov@comparativestudies.ru
}

\begin{abstract}
This article tackles the issue of interconnectedness between the global economic crisis in 2008 and the "For Fair Elections" movement in Russia in 20II-20I2. Studies have shown that the 2008 crisis has affected political attitudes of Russian citizens that might have contributed to the mass mobilization in 20II-20I2. To test this hypothesis, a dataset covering public protest events from 2008 to 2012 in Perm krai and Tyumen oblast' has been developed. The comparison between the cases demonstrates different dynamics of contention, however, a similar composition of protests: local/urban governance issues are the most frequent, closely followed by political/civil rights and economic demands. The comparison indicates that the connections between the 2008 crisis and the $201 \mathrm{I}-2012$ movement are mostly indirect: economic misfortunes caused some groups to protest; it helped some political parties to create broad coalitions based on these grievances, which later became the pillars of the 2OII-2OI2 movement.
\end{abstract}

\section{Keywords}

contentious politics, post-communism, protest, Russia, subnational politics

\section{Von einer ökonomischen zu einer politischen Krise? Konfliktdynamiken in russischen Regionen (2008-2012)}

\section{Zusammenfassung}

Der Artikel beschäftigt sich mit den Zusammenhängen zwischen der globalen Wirtschaftskrise 2008 und der „Für gerechte Wahlen“-Bewegung in Russland von 20II-20I2. Aktuelle Studien zeigen, dass die Krise 2008 die politischen Einstellungen der russischen Bevölkerung beeinflusst hat. Um diese Hypothese zu überprüfen, wurde ein Datensatz erstellt, der öffentliche Protestveranstaltungen von 2008 bis 2012 in zwei Regionen (Permer Gebiet und die Provinz Tyumen) umfasst. Diese zwei Fälle weisen unterschiedliche Konfliktdynamiken auf. Zugleich ist die Zusammensetzung der Proteste jedoch ähnlich. Die dortigen Proteste sind am häufigsten von lokalen/urbanen Problemen geprägt, gleich gefolgt von Forderungen nach politischen Rechten und Bürgerrechten sowie ökonomischen Themen. Der Vergleich deutet auf indirekte Verbindungen zwischen der Krise 2008 und der Protestbewegung 20 I-2OI 2 hin: Der ökonomische Niedergang führte dazu, dass verschiedene Gruppen öffentlich protestierten. Politische Parteien waren darauf aus, diese Mobilisierungswelle zu nutzen und versuchten, eine breite Koalition zu schaffen, die später die Basis der Bewegung von 20II-20I2 wurde

\section{Schlüsselwörter}

contentious politics, Post-Kommunismus, Protest, Russland, subnationale Politik

\section{Acknowledgement:}

This paper was prepared under the European University at Saint-Petersburg Department Development Partnership Program.

The author has declared that no competing interests exist. 
The global economic crisis of 2008 marked the tipping point for significant transformations in the Russian economy and politics: the $5.6 \%$ economic growth of 2008 turned into steep decline $(-7.8 \%)$ in 2009 ; unemployment rose from 6 to $8.5 \%$; and the consumer confidence index plummeted by 38 points (EMISS 2015; Levada-Center 2015). In contrast to the 1998 crisis, the Russian government faced the challenge well-armed with a budget surplus, small public debt, and significant currency reserves; however, it could not avoid being blamed and growing public dissatisfaction (Robinson 2013). With Vladimir Putin and Dmitri Medvedev's ratings in steady decline and fissures in the Kremlin's electoral machinery (Hale 20II; Gel'man 20I3), the "For Fair Elections" movement, started in December 20II, became a major challenge to the regime (Ross 2015). The movement focused primarily on political issues (procedural legitimacy, political rights and liberties, quality of governance and electoral integrity) and arose to a large extent in the big cities (Zavadskaya and Savelieva 20I4).

The movement did not come out of the blue: the 20072OII cycle was accompanied by an increasing frequency and scale of public protests, encompassing both socio-economic and political issues. Strikes in Pikalevo against the shutdown of the town's main factory in 2009, public outrage against raising tariffs for right-wheeled cars across the country, "Dissenters' Marches", the "Strategy-3I" campaign for the constitutional Article 3I, mass mobilization in defense of the Khimky forest, and the nationalist debacle on Manezhnaya square in Moscow in 20I0: all these events pointed towards the growing ability of Russian citizens to act collectively (Teague 20II). For some scholars, public discontent was an indication of changes in mass attitudes due to worsening economic conditions. Triesman (20I4, 385) argues that "rather than being eclipsed by other issues, perceived economic performance became more tightly linked to respondents' views of Putin and Medvedev, with gloomy economic assessments translating more powerfully into lower approval." Chaisty and Whitefield (2012) also highlight the impact of the 2008 economic crisis on middle class attitudes, especially the strengthening of the link between economic assessment and quality of governance. But were economic misfortunes and assumed dissatisfaction with the government transformed into public display of discontent? And did that contribute to the emergence of the "For Fair Elections" movement in 2OII-2OI2?

In this article, I attempt to trace the links between the 2008 crisis, dissatisfaction with governmental policy, and the 2OII-20I2 movement by comparing protest mobilization from 2008 to 2012 in two cases - Perm krai and Tyumen oblast'. The cases were selected to control for the level of socio-economic development and policy responses, while having the variation in political opportunity structure. I employ protest event analysis (PEA) as primary tool for tracing the dynamics of contention in both cases, but also rely on the documents and media reports. PEA allows gauging the frequency, number of participants, organizers, and, most importantly, demands of every occurred protest alongside a number of other variables. Since this method requires an explicit statement of coding rules and procedures, I start with the brief analysis of its scope and limits, specifics of data collection and coding schemes. Then I turn to the scholarship on general effects of regime transition on mass protests in postcommunist Russia, and eventually focus on the Perm and Tyumen cases to assess the links between economic and political protests.

\section{Protest event analysis as analytical tool}

Protest event analysis (PEA) has been employed in a number of studies concerning contentious politics. It is "a key methodological innovation that emerged within the social movement field itself, and has more recently been adapted and refined to study other research topics" (Hutter 2014, 335). The method originated in the early I960s' context of a major shift in the social sciences towards quantification and large cross-national comparisons, and emergence of new approaches to mobilization. Russet, Gurr and Tilly's works were the first to systematically collect protest event catalogs (Russet 1964; Gurr 1979; Tilly 1978; 1995). PEA is a form of content analysis because catalogs are usually compiled on the basis of texts (police or media reports, observation lists); it thus basically transforms "words to numbers" (Franzosi 1994). There are several pitfalls in the method's application: Tilly $(2002,249)$ noticed that "anyone who builds [event catalogs] worries unavoidably about problems of selectivity, reliability, verifiability, comparability, bounding, and inclusiveness." In other words, every event catalog is based on a preconceived theory of necessary and sufficient conditions delimiting "protest event" as a specific phenomenon. The likelihood of a certain event being counted as related to the expression of discontent relies on a set of conceptualizations that is very important given the shifting boundaries of politics and the dynamic nature of contention (Tilly et al. 2003).

Russia is a particularly interesting case that poses additional challenges for PEA. The large territory and its heterogeneity imply a bias in coverage towards populated metropolitan areas and the problem of sources that can cover the whole country. There are some feasible solutions to these issues, for instance, focusing on a certain type of contention, like in Arce and Mangonnet's (2013) study of road blocking in Argentina, a country that resembles Russia in many ways. Another example can be found in Beissinger's (2002) book on nationalist mobilization in the late 
USSR, which covers demonstrations, strikes, and politically motivated violence from 1987 to 1992 . In his later work with Sasse, he covered mass demonstrations, strikes and mass violence in all East European countries after the 2008 global economic crisis, triangulating the data from major newswire agencies, namely Associated Press, Agence France Presse, Deutsche Presse-Agentur, and Interfax (Beissinger/Sasse 20I4, 365f.). Yet another example is a dataset of labor-related conflicts compiled by Bizyukov from the Center for Social and Labor Rights in Moscow. The timespan of the dataset ranges from 2008 to 20I6. It is explicitly focused on labor-related conflicts such as strikes in different forms, meetings, and demonstrations, and it is based on reports from more than 80 sources on- and offline (Bizyukov 2015). However, focusing on a certain type of events either in terms of issues of repertoire limits the possibility to study the links between different forms of contention as well as between political and economic protests.

A different strategy can be found in Robertson's (2OII; 2OI3) and Lankina's (2OI5) datasets. The former compiled protest events catalogs on the basis of reports from the Ministry for Interior Affairs (MVD) and the Institute for Collective Action (IKD) that cover the period from 1997 to 2000 and from 2007 to 2010 respectively. The MVD dataset consists of 5,822 entries featuring location, time, duration, type and number of participants, and type of demands. A similar coding scheme was applied for the IKD reports with 5,726 entries in the dataset. The sets are very different in terms of their sources and possible bias: the MVD is a state agency while IKD is non-profit left-leaning organization. Similar to Robertson, Lankina developed the dataset, which is based on reports from Kasparov website "March of Dissenters" ("Marsh Nesoglasnyh", namarsh.ru). She counted 4,726 events from 2007 to 2012 ; in addition to traditional variables such as time, location, number of participants, she also coded "protest category": political, economic, legal, environmental, and cultural - the last three were combined into the "civic" category (Lankina 2015: 332) However, the primary source and coding scheme raise concerns about data reliability as the website operates on the basis of a politically motivated correspondent network that might be strongly biased towards reporting specific types of protests. As the data also claim to represent the spatial dimension, namely, the dynamics of contention on sub-national level, the issue of possible bias in reporting should be addressed.

To sum up, existing event catalogs, on the one hand, help to produce and test hypotheses about dynamics of contention, especially about links between different types of demands. Existing applications of PEA in regard to Russia come with the costs of being biased: the most comprehensive datasets have a major flaw inasmuch as they rely on politically-motivated networks that are un- evenly distributed across the country. An attempt to address this specific issue led us to the development of the "Contentious Politics in Russian Regions" event catalog.

\section{The data and case selection design}

In order to overcome the limitations of the event catalogs mentioned above, the "Contentious Politics in Russian Regions" database was developed. Its timespan ranges from 2008 to 20I2, and it covers all Russian regions as they were in 2012. We define "protest event" as individual or collective actions of public claim making/ public expression of grievances towards the government or third parties. We compile our data on the basis of mass media reports that are well-known for their selection bias (see, for example, Koopmans I999; Rucht/ Neidhardt 1999; Koopmans/Rucht 2002; Ortiz et al. 2005; Herkenrath/Knoll 20II). As we have already discussed, media sources are far from being perfect because of editorial policy and standards of reporting specifics, self-censorship and selective attention of journalists. In addition, the Russian media environment has been constantly shrinking, hence, the poor quality of news accounts; for instance, estimates in a number of protest actions participants can vary significantly (Oleinik 20I4). However, alternative sources, including public agencies reports or observation lists, are even worse (Lobanova/Semenov 2013). One possible solution is to anchor the data not in one source, but rather in a set of different sources, in our case the "Integrum" media database, which aggregates reports from more than 40,000 Russian media outlets, including regional and local newspapers and stores more than one billion reports. The particularities of the coding sources and procedures are reported in Appendix I.

I employed paired comparison and picked two regions (Tyumen oblast and Perm krai) to address the research question. Both regions have strong - though different - economies (Table I.), but contrast in regards to politics: Perm krai is well-known for its relatively high level of political competition and civic engagements, while in Tyumen opposition has been marginalized and dislodged from the public sphere (Borisova 2010; Lobanova/Semenov 2015). Hence, it is possible to compare the dynamics of contention in different political settings controlling for economic indicators.

Case selection follows Blatter and Haverland's (2012, 42) suggestion of three possible options: co-variational analysis to look for the same mechanisms in diverse cases, and causal process tracing and congruence analysis as within-case techniques for alternative hypothesis testing. Our strategy combines all of them through generating alternative mechanisms at the first stage and testing them both within and between cases. As for case 
Table 1: Basic socio-economic indicators in 2011: Perm and Tyumen. Source: Russian Federal Statistics Agency, http://www.gks.ru/.

\begin{tabular}{|l|c|c|c|c|c|}
\hline & population & $\begin{array}{c}\text { Average monthly } \\
\text { wage (real prices), } \\
\text { RUB }\end{array}$ & $\begin{array}{c}\text { Number of } \\
\text { extractive } \\
\text { enterprises }\end{array}$ & $\begin{array}{c}\text { Fixed capital } \\
\text { investment, } \\
\text { mln RUB }\end{array}$ & $\begin{array}{c}\text { GRP 2011, } \\
\text { mln RUB }\end{array}$ \\
\hline Perm & 2631100 & 25503.9 & 27 & 76858.4 & 319149.5 \\
\hline Tyumen & 3459400 & 32956.1 & 21 & 43396.5 & 522064.8 \\
\hline
\end{tabular}

selection, again, we use Blatter and Haverland's ideas that, first, it must be deliberative (non-random), second, there must be presence of co-variation in the independent variable among cases, and, lastly, cases should be as similar as possible in the variable one seeks to control. The cases of Perm krai and Tyumen oblast' meet these requirements: control socio-economic conditions are almost similar, while the degree of civic engagement and protest activity varies.

\section{The context: Dynamics of contention in post-Soviet Russia}

The dramatic changes in Russia's societal landscape during the post-communist transition so far have been thoroughly documented and assessed. Though Russia has not become a full-fledged democracy, its economy and politics have gone far from the Soviet era (Gel'man 2015). Twists and turns in regime dynamics have been accompanied with the general decline of mass public engagement in politics: the "World Values Survey" indicates that while $29.6 \%$ of the population in 1990 said that they signed a petition (with $44.1 \%$ that might do) in 2005 only $7.7 \%$ did (with 28.7 that might do). During the I990s, on average $25.5 \%$ claimed that they participated in lawful demonstrations while in 2005 only $13.4 \%$ answered that they had attended demonstrations in the last five years (World Values Survey 2016). According to the last WVS data (20IO-20I4) Russians are less likely to sign a petition than citizens of the other East European Countries: $31.7 \%$ did not sign a single petition compared to $2 \mathrm{I} .4 \%$ in Estonia; $20.2 \%$ of Russians and $46.5 \%$ of Estonians took part in peaceful demonstrations. Major Russian pollster Levada center confirms these developments: in April 20II only 3\% attended public protest actions and $2 \%$ participated in strikes. Although during the 2000 s, IO to II\% of respondents were willing to join public protests, the vast majority (about 79 to $80 \%$ ) was not (Levada-Center 2015).

In the end, the mass mobilization during the Perestroika and its unprecedented wave of ethnic and nationalist movements (Beissinger 2002), tens of thousands of street protesters, and numerous grass-root activists, including political clubs (Sigman 2009), were followed by the withdrawal of masses from politics, largely attributed to increased economic burdens, relative deprivation, and overall political loyalty of Russian population (Minin 2005). However, protest politics did not disappear into thin air: the same economic downturn produced wage arrears that resulted in a wave of strikes, spearheaded by coalminers, from 1995 to 1999. According to official statistics, the number of strikes exceeded 17,000 in 1997, and subsequently decreased almost to non-existence in 2008-2009 (Kozina 2009). All in all, Boris Yeltsin's presidency resulted in 53,366 strike events from 1993 to 1999, while Vladimir Putin's first two terms in the office yielded 9,782 in counts (Rosstat 2015).

Upon Putin's arrival to the presidential office in 2000, the Russian state was largely decentralized and weak, while governors and regional political machines played major roles in organizing political life and mobilizing the public (Robertson 20II). Putin's policy of power centralization led to shrinking political opportunity structures. The spill-over effects of the "color revolutions" in Serbia, Georgia, Ukraine, and Uzbekistan in the 2000 s also affected the way the political regime in Russia treated mass protests: major restrictions on party and NGO activities were passed in 2002 and 2006; the regulation of public meetings and rallies was amended with increased fines and requirements, alongside with state assault on independent media and large pro-Kremlin mobilization (Smyth et al. 2013).

Therefore, the overall level of contention has been largely determined by regime dynamics itself, ranging from regional-based elite-manipulated protests on economic issues in the second half of the I99os to periods of quiescence - thanks to revived economic growth and tailored instrument of policing the protests - in the early 2000 s. Nation-wide campaign against the monetisation of in-kind benefits erupted in 2005, followed by grass-root mobilization on different issues ranging from urban development to environment (Clément 2008). On the outset and during the global crisis of 2008-2009, protests in Vladivostok and Kaliningrad took political elites by surprise (Clément 2009; Teague 20II). Comparing the I990s to the 2000s, Robertson highlights the sharp turn in the content of protest demands: in the late 
I990s, 72 to $74 \%$ of events were focused on wage arrears and labor-related issues (demands for changes in politics/policy accounted for $5 \%$ combined), whereas in the late 2000 , the same issue of arrears was raised no more than in $6 \%$ of all events. Robertson $(2013,16)$ also notes that "the most striking transformation in protest in Russia between the I990s and the second half of the PutinMedvedev era is a dramatic shift from protest dominated by direct actions ... to one in which the vast majority of protest events are purely symbolic in nature."

This transformation from strikes and road blockades to demonstrations and marches indicates a change in Russian politics and society: while the major protests in the I990s were associated with grievances revolving around wage arrears and other basic material needs, $28 \%$ of protests in the second half of the 2000 sere concerned with urban development/environmental issues, with demands for political changes following (22\%). Surprisingly, civic rights issues have the third largest share (16\%). Locations changed as well: during the Yeltsin presidency, the vast majority of protest events happened in the regions (in 1997 more than 97\%); but in the 20oos, a dramatic shift to the capitals occurred with protest events more and more concentrated in Moscow ( $44 \%$ of the total in 2OII) and to a less extent in St. Petersburg. Robertson (2OI3, 2I) concludes:

Citizens are increasingly, it seems, willing or able to make connections between material issues and more abstract issues like civil rights or election fraud. Moreover, as the set of concerns that lead to protest becomes more diverse, so the human and organizational capital that can be drawn on to challenge the authorities becomes both more widely diffused and stronger.

In his view, this development contributed to the formation of the "For Fair Elections" movement in 2OII-2OI2. This movement emerged shortly after the 2OII State Duma elections. The slogan was invented by the "Solidarnost" movement for the public meeting at "Chistye Prudy" in Moscow on December 5, and quickly became the name for the nation-wide campaign that managed to sustain for almost a year. "For Fair Elections" was comprised of diverse groups and networks, most of them without prior political experience but somehow related to non-political initiatives. The core of the movement was comprised of educated urban professionals, though nearly all major socio-demographic groups were present (Lobanova/Semenov 20I2; Volkov 20I2). The movement stretched far beyond the capital and became a major political challenge to Putin's regime, which in turn introduced a full set of measures to corner and defeat the protesters with new legislation on public meetings, targeted arrests and prosecution, and anti-movement propaganda (Smyth et al. 20I3). Eventually, despite the large number of initial participants, media salience and creativity of protesters, the movement died out due to its restricted geographical and generational scope and internal cleavages (Koesel/Bunce 2OI2).

\section{Transformation of contention in Russian regions (2008-2012): Perm and Tyumen compared}

To explore the dynamics of protests after the 2008 global economic crisis in more detail, I zoom into the cases of Perm krai and Tyumen oblast'. Due to its industrial economic profile, the former was hit harder by the crisis. In 2009, the industrial output index declined by 14.8 points (in Tyumen it rose by 2.8 points), unemployment increased to its peak of II\% in 2010 (in Tyumen $7.8 \%$, in Russia on average $8.7 \%$ ). For the first time in the 2000 , wage arrears appeared as an issue (EMISS 2015). Nevertheless, both regions weathered the storm quite well with policies designed to reduce the impact of the economic downturn, including budget optimisation, tax reductions, and refinancing through the accrued reserves (Starodubrovskya et al. 20IO). From these accounts one would expect the degree of contention to be higher in Perm, due to the more competitive political regime and the larger impact of the economic crisis. One might also expect actors to coalesce and redirect their claims towards the central government, assuming that the economic crisis pushed citizens towards a more critical evaluation of government performance and considering the growing number of participants and the increased frequency of events prior to the onset of the "For Fair Elections" campaign.

Between 2008 and 2012, 330 events for Tyumen and I66 for Perm were reported, the vast majority (93-95\%) of which happened in regional capitals. Figure I. shows the dynamics of protest events in Tyumen and Perm. In

Figure 1: Dynamics of protest events in Perm and Tyumen (2008-2012). Source: author's calculations based on Integrum media reports.

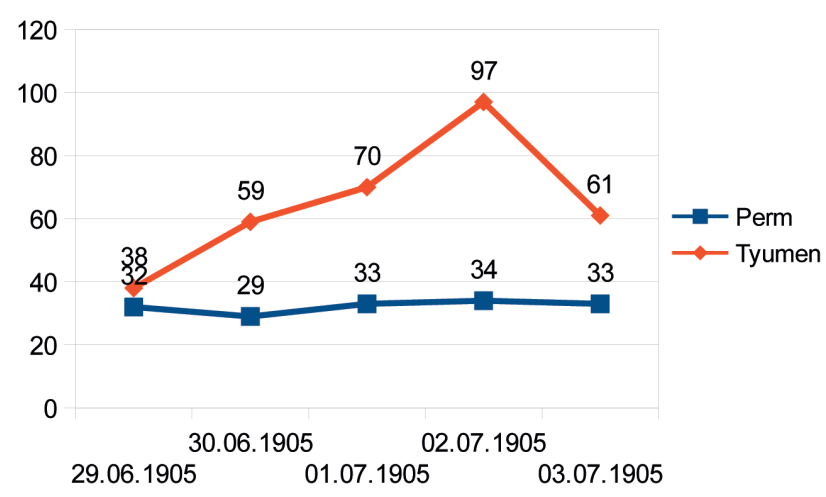


Table 2: Core issue frames, pooled data from Perm and Tyumen (2008-2012).

Source: author's calculations based on Integrum media reports.

\begin{tabular}{|c|c|c|c|}
\hline Rank & Issue Frame & $\begin{array}{l}\text { Total } \\
\text { Number }\end{array}$ & $\%$ of Total \\
\hline 1. & $\begin{array}{l}\text { Urban/ local politics (hoodwinked investors, infill construction, } \\
\text { construction demolition, urban green zones etc.) }\end{array}$ & 102 & 19,2 \\
\hline 2. & Basic political and civic rights & 96 & 18,1 \\
\hline 3. & State of economy (wages, taxes, monetary policy, public budget etc.) & 79 & 15 \\
\hline 4. & $\begin{array}{l}\text { Quality of governance (transparency, corruption, functioning of public state/ } \\
\text { municipal institutions etc.) }\end{array}$ & 43 & 8,1 \\
\hline 5. & Social policy (education, healthcare, pensions etc.) & 38 & 7,2 \\
\hline 6. & Memory politics (including traditional communist events) & 37 & 7 \\
\hline 7. & All other issues & 32 & 6 \\
\hline 8. & Elections fraud, electoral politics & 31 & 5,9 \\
\hline 9. & Environment & 19 & 3,6 \\
\hline 10. & Religious rights & 17 & 3,2 \\
\hline
\end{tabular}

the former case there is an upward trend with its pinnacle of 97 events in 20II, while in the latter the trend is not as clear. The total number of participants (with exclusion of traditional communist actions on the ist of May and 7 th of November) for the five years period is 17,8 thousands participants in Tyumen (4.4 protesters per Iooo inhabitants) and about I8 thousands in Perm (I.9 protesters per Iooo inhabitants). Therefore, the aggregated statistics shows that the overall degree of contention in Tyumen was higher than in Perm.

The categorisation of protest demands should be considered with some caveats, because at virtually every event multiple claims were made. Hence, I coded the most frequent claim as core category, then assigned up to two other types if necessary. The codebook comprises 2I categories; 31\% of events in Tyumen and 38\% in Perm were considered to be "complex" with more than one category attached. Table 2. presents the aggregated statistics for the ten most frequent categories.

Almost every fifth protest focused on local/urban development issues: infill constructions, hoodwinked household investors, defense of parks, green zones, and other recreational areas, architectural and historical legacy preservation. Political and civic rights protests (against political repressions, for the freedom of speech, freedom of assembly, against constitutional amendments etc.) appear with roughly the same frequency. The state of the economy (wages, taxes, public spending) accounts for $15 \%$ of protest events.

Our data to some extent confirms Robertson's (2OI3) observations that in the 2000s, the Russian population was predominantly concerned with "growth problems" and shifted their mode of action from direct to symbolic. In our sample, wage arrears and protests against the shutdown of certain enterprises occurred, but constituted a small fraction of the overall number, while demands for the better life quality, basic rights, and economic welfare dominated. It is important to note that the repertoire employed by protesters is indeed symbolic par excellence with conventional forms like demonstrations, marches, meetings, and pickets accounting for $76 \%$ of events in Perm and $91.5 \%$ in Tyumen. In the Perm region, I4 (8.4\%) direct actions (road blockades, spontaneous gatherings, or protest camps), il art performances (6.6\%), 9 hunger strikes (5.4\%), 3 motor rallies and 2 strikes were encountered. In Tyumen, the repertoire was less diverse and comprised mostly of direct actions (I9 events) alongside, six art performances, two motor rallies and a hunger strike.

Zooming into the particularities of demand dynamics, I tracked three major categories and found significantly diverse trajectories in our cases (Figures 2 and 3). In Tyumen, all categories were on the rise with the climax in $201 \mathrm{I}$ and sharp decline afterwards. In Perm, all categories were in slight decline, with the exception of urban development issues that rocketed on the same 2olr year, due to the big campaign in defense of the constitutional 3rd Article (it states that Russia is a "social state") launched by the Coordination Council for Protest Actions (CCPA), an umbrella organisation that united a number of grass-roots groups. The campaign specifically targeted a bulk of local issues including construction and maintenance of accommodation for low-income citizens, privatization of communal apartments, and demands for the city mayor's direct elections. On the sidelines, hoodwinked housing investors also took part in the street protests. 
Figures 2 and 3: Core issue frames in Tyumen (left) and Perm (Right). Blue - economy, orange - urban politics, yellow - political and civic rights. Source: author's calculations based on Integrum media reports.

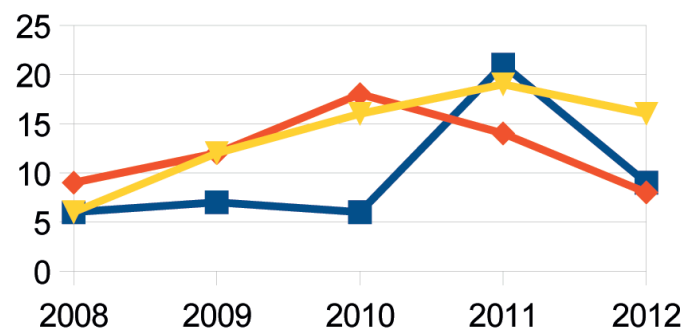

In Tyumen, the economic agenda and civic rights issues dominated. Because of the electoral cycle, communist parties specifically targeted the raising prices and inefficiencies of social policy, housing and utility infrastructure; in addition, a separate campaign took place against the bankruptcy of the TUANN enterprise, which resulted in a mass firing of its employees. Civic rights were advocated both by Strategy-3I events (a series of civic protests in support of the right to peaceful assembly in Russia guaranteed by Article 3I of the Russian Constitution) and later at the onset of the "For Fair Elections!" campaign.

Other significant differences appear in the "organiser-demand" linkage. In Tyumen, $48 \%$ of economic protests were organized by the Communist Party of the Russian Federation (KPRF) and the Russian Communist Labor Party (RKRP), while in Perm there was no leading actor in this regard. A diversity of organizers was also behind urban issues including local initiative groups, civic activists, and political parties. Finally, civic and political rights actions were spearheaded by anarchists, the RKRP and the "Volya" (The Will) party. In Perm, civic activists and the CCPA were at the forefront. The regions also differ regarding the primary target of action: while in both cases the federal government and the president were the first to be blamed ( $47 \%$ in Tyumen and 37\% in Perm), regional government and private companies were under more pressure in Perm $(23 \%$ and $14 \%$ of the incidents vs. I0\% and 9\% in Tyumen). Meanwhile, in the Siberian region, attempts to address the "society at large" were five times more frequent than in Perm ( 56 vs. II actions). Local authorities in both cases also attracted considerable attention: $\mathrm{I} 2 \%$ public protests in Tyumen and $16 \%$ in Perm targeted them.

Given the industrial profile of the region, Perm faced more crisis-related protests than Tyumen. In July 2009, the regional industry leader "Kama Cable" had to fire 900 employees and faced a public campaign supported by the regional branch of the Communist Party. In September, the workers of "Kizel crane" factory blocked the road because of wage arrears. A month later, workers of the military giant "Perm Powder Factory" went on a strike. As the economy started to recover in 20I0, the industrial

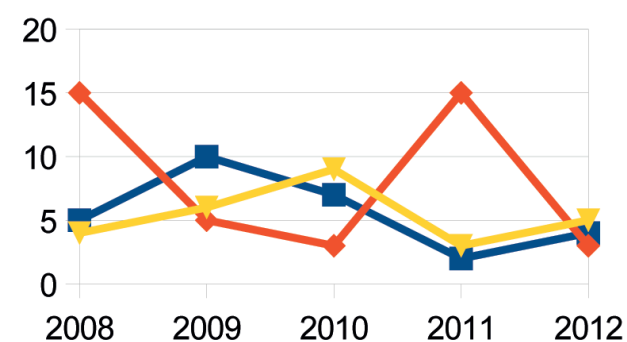

protests faded away. In Tyumen, however, the crisis hit differently: due to the credit crisis a number of constructions in the city were frozen while construction companies went bankrupt. This caused individual investors to turn from courts to streets: from 2009 to 20I2, "hoodwinked house investors" groups organised 22 public protests targeting the regional government and demanding compensations. The government officials (Vice-Governor and the Head of regional Department for Nationalities Affairs) were sent to pacify the groups; the most active participants eventually got compensations.

The global economic crisis and its consequences became a major topic for the left-wing political groups like the KPRF and the RKRP in Tyumen or the CCPA in Perm. The two former held public meetings on September 18 and October I7, 2009, respectively, when up to 200 participants were present. In 2010 the issue again was raised by the KPRF in the context of the anti-crisis policy. In October 2010, communists joined diverse groups and organisations (from liberals to anarchists) in creating the Council of Initiative Groups and Citizens (CIGC), which for a while became the major force behind the public protests, including the "For Fair Elections" campaign. In Perm, the CCPA was the first to mention the 2008 crisis at their public rally on October 25,2008 . In 2009, the CCPA organised three protest actions, focusing on the distressful situation of disadvantaged groups like workers (with slogans like "Workers do not have to pay for the crisis!", "No to job cuts!"), families in living communities ("Russia is a country of homeless", "The authorities make us homeless!"), pensioners and poor ("People against rise in prices").

At this stage I can conclude that some of the theoretical expectations proved to be right, while others only partially fit the empirical evidence. In both cases, attempts to forge anti-status-quo coalitions ended with the creation of umbrella organisations that later became the backbones of the "For Fair Elections" movement. In Tyumen, the CIGC initially emerged on top of an anticorruption campaign in the city, and afterwards turned into a forum for debates and coordination among political parties and local protest groups. According to its protocols, the question of linking political and economic 
demands was raised numerous times, especially in winter of 2OII-20I2. On March IO, 2OI2, at a regular Council meeting, a KPRF member announced the next public rally and was immediately confronted by another Council member with the following question: "Why [for fair elections] meeting? Maybe it is better to have a meeting on communal tariffs?" Yet another participant noticed that "it is necessary to search for other points of attraction, where economic and social contradictions are erupting" and that "social issues might bring much more people to the streets than elections" (Protokol zasedaniya Soveta Iniciativnuyh Grupp I Grazdan ot IO marta 2012). Following this discussion, economic demands were added to the list of claims. This, however, only happended at the very end of the "For Fair Elections" movement, when the majority of participants had demobilized and only the "hard core" of the movement (party members par excellence) remained (Lobanova/Semenov 2015). In Perm, a similar role was played by the CCPA and the Council of December 24. The former played a major role in mobilizing citizens around urban issues, bringing together demands of a patchwork of groups. The latter was an attempt to coordinate the "For Fair Elections" movement; civic activists dominated in the Council, restricting the agenda to mostly political issues.

The data also prove that there was a steady growth of the frequency and the number of participants in protests, though, to a lesser degree in Perm. Indeed, prior to the onset of the "For Fair Elections" campaign, in both cases numerous political and non-partisan groups and organisations were engaged in the acts of public dissent with different levels of governance as primary target and federal government receiving the growing number of claims. However, the analysis disconfirms that hypothesis that the Perm region should have experienced a higher degree of discontent due to its vulnerability to economic shocks and its competitive political regime; on the contrary, in relatively well-off Tyumen the steep rise in contention was clearly visible both in frequency and number of protesters. This can be due to the inverse U-shape relations between political opportunity structures and protests, a well-known phenomenon in mobilization studies, but further research is required to prove this assumption.

\section{Conclusions}

The dynamics of contention in post-Soviet Russia seem to follow general patterns of "protest cycles" (Tarrow 1993) with ebbs and flows of mobilization across the country. The general assumption that Russians are disengaged from politics is at odds with accounts based on existing event catalogs, which also detect major shifts in demand categories, repertoire, and target of protest actions. This study confirms these findings: indeed, in the two cases under scrutiny the protests increased in frequency, attracted a growing number of participants, were symbolic in nature, revolved around local issues, civic rights and the state of economy, and primarily targeted the central government. However, it also shows a great variation in dynamics, composition of demands and actors, targets, and repertoire. Hence, this analysis highlights the importance of the subnational level in studying countries like Russia: even within the same category of regions, one can find significant differences in political dynamics.

The links between the global economic crisis in 2008 and the political upheaval of 20II-2OI2 were everything but straightforward: economic misfortune directly affected some groups like the industrial working class and private investors, who employed the protest tactics in order to obtain concessions from their employers or the state. On several occasions they were approached by political parties (mostly leftists); in both cases this resulted in a sustained cooperation under the umbrella of "councils" (Coordination Council for Protest Actions in Perm, Council of Initiative Groups and Citizens in Tyumen). In 20II, these organisations became the pillars (one out of many, though) of the nascent "For Fair Elections" movement.

Likewise, the analysis shows that political and civic rights were not neglected or overshadowed by "breadand-butter" issues. Instead, in both cases demands related to politics and economy are almost even, but far from constituting a majority of claims. Compared to the I990s, when wage arrears overwhelmingly dominated, it is remarkable how diverse protest demands became in late 20oos. The finding that "local/urban" issues are at the forefront of contention in contemporary Russia also fits well with recent studies on "urban regimes" (Ledyaev 20I2; Tykanova/Hohlova 20I5) and grass-roots activities (Clément et al. 2010), which document the contradictions between urban "growth coalitions" and local communities. Notwithstanding the fact that protests based on local agenda cannot be easily rescaled to nation-wide demands and become a basis for national campaigns and movements, local initiatives remain an important venue for citizens' engagement in collective actions in the pursuit of public good.

In the end, "the patience" of Russian society is a matter of comparison: compared to "rebellious" Poland or Hungary, the Russian population exerts a much smaller degree of organised and sustained contention. But acknowledging the overall trajectory of the regime towards consolidated authoritarianism, the rare, short and seemingly unconnected waves of political mobilization reflect the shrinking political opportunity structures. On the other hand, the scale of local and regional contention presented here proves that worsening condi- 
tions for the expression of public grievances might turn Russians to the streets once again.

\section{References}

Arce, Moisés/Jorge Mangonnet (2013). Competitiveness, Partisanship, and Subnational Protest in Argentina, in: Comparative Political Studies, Vol. 46(8), 895-9I9.

Blatter, Joachim/Markus Haverland (2012). Designing Case Studies: Explanatory Approaches in Small-N Research, New York.

Borisova, Nadezda (20I0). Perm: lokal'nyi regime v krupnom rossiiskom gorode [Perm: Local Regime in a Big Russian City], in: Nerpikosnovennyi zapas, Vol. 7O(2), 92-IO3.

Beissinger, Mark (2002). Nationalist Mobilization and the Collapse of the Soviet State, Cambridge.

Beissinger, Mark/Gwendolyn Sasse (20I4). An End to "Patience"? in: Bermeo, Nancy/Larry Bartels (eds.): Mass Politics in Tough Times: Opinions, Votes and Protest in the Great Recession, Oxford, 334-370.

Chaisty, Paul/Stephen Whitefield (2012). The Effects of the Global Financial Crisis on Russian Political Attitudes, in: Post-Soviet Affairs, Vol. 28(2), I87-208.

Clément, Karine (2008). New Social Movements in Russia: A Challenge to the Dominant Model of Power Relationships? in: Journal of Communist Studies and Transition Politics, Vol. 24(I), 68-89.

Clément, Karine (2009). Profsoyuznoe rabochee dvizheniev 2009 godu[The Trade Union and Workers' Movement in 2009]. Internet: http://www.ikd.ru/node/ I2I34/print (accessed: I2.06.20I6)

Clément, Karine et al. (2010). Ot obyvatelei k aktivistam: zarozdayussiesya socialnye dvizheniya v sovremennoi Rossii [From Bystanders to Activists: Emerging Social Movements in Contemporary Russia], Moscow.

EMISS (2015). Integrated Interagency InformationalStatistical System Website. Internet: http://fedstat. $\mathrm{ru}$ / (accessed I 2.06.20I6)

Franzosi, Roberto (1994). From Words to Numbers: A Set Theory Framework for the Collection, Organization and Analysis of Narrative Data, in: Sociological Methodology, Vol. 24, I05-I36.

Gel'man, Vladimir (20I3). Cracks in the Wall: Challenges to Electoral Authoritarianism in Russia, in: Problems of Post-Communism, Vol. 6o(2), 3-IO.

Gurr, Ted (ed.) (I979). Violence in America: Protest, Rebellion, Reform, Vol. 2, Newbury Park, CA.

Hale, Henry (20II). The Putin Machine Sputters: First Impressions of the 20II Duma Elections Campaign, in: Russian Analytical Digest, I06, 2-5.

Herkenrath, Mark/Alex Knoll (20II). Protest Events in International Press Coverage: An Empirical Critique of Cross-National Conflict Databases, in: International Journal of Comparative Sociology, Vol. 52(3), I63-I80.

Hutter, Swen (2014). Protest Event-Analysis and Its Offspring, in: della Porta D. (ed.): Methodological Practices in Social Movement Research, Oxford, 335-367.

Koopmans, Ruud (1999). The Use of Protest Event Data in Comparative Research: Cross-National Comparability, Sampling Methods and Robustness, in: Dieter Rucht/Ruud Koopmans/Friedhelm Neidhardt (eds.): Acts of dissent: New developments in the study of protest, Lanham, 90-IIo.

Koopmans, Ruud/Dieter Rucht (2002). Protest Event Analysis, in: Bert Klandermans/Susan Staggenborg (eds.): Methods of Social Movement Research, Minneapolis, MN, 23I-259.

Lankina, Tomila (2015). The Dynamics of Regional and National Contentious Politics in Russia: Evidence from a New Dataset, in: Problems of Post-Communism, Vol. 62(I), 26-44.

Ledyaev, Valeri (2012). Sociologiya vlasti: teoriya i opyt empiricheskogo issledovaniya vlastii $\mathrm{v}$ gorodskih soobssetvah [Sociology of Power: Theory and Practice of Empirical Study of Power in Urban Communities], Moscow.

Levada-Center (2015). Obschestvennoe mnenie - 2015 [Public Opinion - 20I5]. Internet: http://www.levada. ru/sbornik-obshhestvennoe-mnenie/obshhestvennoe-mnenie-2015/ (accessed I2.06.2016)

Lobanova, Olesya/Andrey Semenov (2015). Civic Protests in Tyumen Region: December 2OII-September 20I2, in: Cameron Ross (ed.): Systemic and Non-Systemic Opposition in the Russian Federation: Civil Society Awakens? Abingdon/New York, I79-198.

Lobanova, Olesya/Andrey Semenov (2013). Kak lyudi i organizatsii trebuyut izmenenii: issledovaniye repertuara protesta v Tyumeni [How People and Organizations Demand Changes: A Study of Protest Repertoire in Tyumen], in: Monitoring obsestvennogo mneniya, Vol. 6(II8), 30-38.

McAllister, Ian/Stephen White (20II). Democratization in Russia and the Global Financial Crisis, in: Journal of Communist Studies and Transition Politics, Vol. $27(3-4), 476-495$.

Bizyukov, Piotr (20I5). Metodika i informacionnaya baza monitoringa trudovyh protestov CSPT [Methodics and informational sources for labor conflict monitoring] Internet: http://trudprava.ru/expert/analytics/protestanalyt/I360 (accessed: I2.05.20I5).

Oleinik, Anton (2014). On Content Analysis of Images of Mass Protests: A Case of Data Triangulation, in: Quality and Quantity, Vol. 49(5), I-I8.

Ortiz, David et al. (2005). Where do We Stand with Newspaper Data? in: Mobilization: An International Quarterly, Vol. IO(3), 397-4I9. 
Protokol zasedaniya Soveta Iniciativnuyh Grupp I Grazdan ot IO marta 2012 [Council of Initiative Groups and Citizens meeting protocol, March Ioth, 2OI2], in: author's archive.

Robertson, Graeme (20II). The Politics of Protest in Hybrid Regimes: Managing Dissent in Post-Communist Russia, Cambridge.

Robertson, Graeme (2013). Protesting Putinism: The Election Protests of 2OII-2OI2 in Broader Perspective, in: Problems of Post-Communism, Vol. 6O(2): II-23.

Robinson, Neil (2013). Russia's Response to Crisis: The Paradox of Success, in: Europe-Asia Studies, Vol. 65(3), 450-472.

Ross, Cameron (2015). Systemic and Non-Systemic Opposition in the Russian Federation: Civil Society Awakens? Abingdon/New York.

Rosstat (2015). Edinaya mezvedomstvennaya informacionno-statisticheskaya systema [Integrated Intragovernmental Informational-Statistical System]. Internet: www.fedstat.ru/indicators (accessed: I2.06.2016)

Rucht, Dieter/Friedrich Neidhardt (1999). Methodological Issues in Collecting Protest Event Data: Units of Analysis, Sources and Sampling, Coding Problems, in: Dieter Rucht/Ruud Koopmans/Friedrich Neidhardt (eds.): Acts of Dissent: New Developments in the Study of Protest, Lanham, 65-89.

Russett, Bruce M./Hayward R. Alker Jr./Karl W. Deutsch/ Harold D. Lasswell (1964). World Handbook of Political and Social Indicators, New Haven.

Semenov, Andrey (20I4). Partiinye i vnepartiinye aktory v izbiratelnyuh kampaniyah: opyt Tyumenskoi oblasti [Parties and Non-Partisan Actors in Election Campaigns: The Case of Tyumen], in: Vestnik Permskogo unviersiteta, seriya "Politologiya", Vol. 3, 65-75.

Smyth, Regina/Anton Sobolev/Irina Soboleva (2013). A Well-Organized Play: Symbolic Politics and the Effect of the Pro-Putin Rallies, in: Problems of Postcommunism, Vol. 6o(2), 24-39.

Starodubrovskaya, Irina/Natalia Zubarevich/Vladimir Nazarov (20IO). Analiz regional'noi antikrizisnoi politiki [Analysis of Regional Anti-Crisis Policy], Moscow.

Teague, Elizabeth (20II). How Did the Russian Population Respond to the Global Financial Crisis? in: Journal of Communist Studies and Transition Politics Vol. $27(3-4), 420-433$.

Tilly, Charles (1978). From Mobilization to Revolution, New York.

Tilly, Charles (1995). Popular Contention in Great Britain I758-I834, Cambridge.

Tilly, Charles (2002). Event Catalogs as Theories, in: Sociological Theory, Vol. 2O(2), 248-254.

Treisman, Daniel (2014). Putin's Popularity since 20IO: Why Did Support for the Kremlin Plunge, then Stabilize? In: Post-Soviet Affairs, Vol. 30(5), 370-388.
Tykanova, Elena/Anisya Hohlova (2015). Gorodskoi politicheskii regime v Sankt-Peterburge: rol' realnyh i voobrazhaemyh "mashin rosta" v borbe za gorodskoye prostranstvo [The Urban Political Regime in St.Petersburg: The Role of Real and Imagined "Growth Machines" in the Struggle for Urban Space], in: Jurnal issledovanii socialnoi politiki. Vol. I3(2), 24I-256.

Volkov, Denis (2012). The Protesters and the Public, in: Journal of Democracy, Vol. 23(3), 55-62.

World Values Survey Association (2016). World Values Survey I98I-20I4 Longitudinal Aggregate v.20I504I8. Internet: http://www.worldvaluessurvey.org (accessed I2.06.2016)

Zavadskaya, Margartia/Natalia Saveleva (20I4). "A mojno ja kak-nibud sam vyberu?": vybory kak "lichnoe delo", procedurnaya legitimnost I mobilisatsiya 20II2012 godov ["Can I Choose by Myself?" Elections as a Personal Cause, Procedural Legitimacy, and Mobilization of 20II-20I2], in: S. Erpyleva/A. Magun (eds.): Politika apolitichnyh: socialnye dvizenija v Rossii 2OII-2OI3 gg. (The Politics of Apolitical: Social Movements in Russia in 2OII-20I3), Moscow.

\section{Author}

Andrey Semenov (1984) is Director of the Center for Comparative History and Politics, University of Perm, Russia. He holds a Candidate of Science degree in Politics from the University of Perm (20IO). His research interests are comparative politics, social movements, contentious politics, political participation, and subnational politics. Latest publications include "When do Political Parties Join Protests? A Comparative Analysis of Party Involvement in 'For Fair Elections' Movement" (East European Politics, 2016) and "Civic Protests in Tyumen Region: December 2OII-September 2012" (Systemic and Non-Systemic Opposition in the Russian Federation, 2OI5). 


\section{Appendix 1}

\section{Coding sources and procedures}

Our event catalog is built upon the "Integrum" media database, which aggregates reports from more than 40,000 Russian media outlets, including regional and local newspapers. It currently stores more than I billion reports. This database has its own search engine with standard search syntax rules for specific queries. It also allows to restrict retrieval to a required timespan or location and to filter the sources. After testing several search queries we came to the following request:

«акци* протест* ("protest action”)

Quotation marks were used to restrict search results to this particular collocation, while asterisks were necessary to control for differences in morphology. We also ensured that available regional and local newspapers are included in retrieval. As a result, we were able to cut off the majority of irrelevant results (e.g. "protests" of prosecutors/advocates in judicial trials) and managed to capture a large number of protest events outside the capital.

The next step was to select all relevant reports fitting our definition of "protest event". We counted all events within Russian boundaries, regardless of the citizenship of claim makers. We also did not restrict our definition of protest event to a threshold of a certain participants number to capture specific forms of contestation like single-person picket (a widespread tactics in Russia that allows to bypass legislative requirements for organizing a public event). We set basic variables (time, location, duration, organizer, demands) for each event/observation unit; whenever three of the five basic variables were absent, the event was not counted. The codebook incorporated 23 variables. To ensure the common understanding of coding rules and resolve ambiguities, coders worked in full working environment with supervision, log of all issues was kept, and once in two weeks the group met to resolve the most difficult issues by consensus. 
